\title{
A Procedure for Simultaneous Preparation of Large Amounts of DNA and RNA by the Use of Potassium lodide Gradients
}

\author{
HANS WOLF ${ }^{1}$ \\ Institüt für Klinische Virologie der Universität Erlangen-Nürnberg, \\ 8520 Erlangen, Loschgestrasse 7, Germany
}

Received January 16, 1975; accepted May 5, 1975

\begin{abstract}
A method is described that permits the isolation of both DNA and RNA from tissues on KI density gradients without destroying either nucleic acid species. Up to $3 \mathrm{mg}$ can be resolved efficiently in a single $13-\mathrm{ml}$ gradient. Data are presented which show that direct monitoring of the OD of nucleic acids in KI solutions is possible without addition of ethidium bromide. Furthermore, equations for the correlation of density, refractive index and weight per volume are presented.
\end{abstract}

Investigations of tumor viruses and their expression in host cells often require preparation of large amounts of both DNA and RNA. There exist several reasons for obtaining both nucleic acids from the same sample of tissue: First, to be sure that RNA and DNA are derived from exactly the same region of biopsy material. Second, to overcome problems due to small amounts of available tissue. Finally, the methods used should be inexpensive for preparative work and should permit convenient handling with standard laboratory equipment.

Cesium salts are not suited for this purpose because RNA has a low solubility in $\mathrm{Cs}_{2} \mathrm{SO}_{4}$ solutions and $\mathrm{CsCl}$ cannot provide a sufficiently high density. Alkali iodides have been introduced for DNA density gradients by Anet and Strayer (1). De Kloet and Andrean (2) compared different gradient media and reported potassium iodide to be optimal for separation of DNA from RNA. J. M. Bishop and co-workers ${ }^{2}$ found that preformed KI gradients are useful for separating DNA from RNA.

The methods described by these authors suffer from the disadvantage of requiring fluorimetric evaluation of the gradient fractions in the presence of a dye like ethidium bromide. Moreover, there is no information available about the capacity of these gradients nor about the correlation between refractive index $(n)$, buoyant density and weight of KI per vol-

\footnotetext{
' Present address: Committee on Virology, The University of Chicago, 939 East 57th Street, Chicago, IL 60637

${ }^{2}$ Personal communication.
} 
ume. These difficulties have been overcome in the present work which shows that there exists no need for adding any dye in order to monitor nucleic acids and that the capacity of potassium iodide gradients is very high with excellent separation and extremely little trapping. Furthermore, some technical information concerning these gradients has been provided.

\section{MATERIALS AND METHODS}

Materials. KI, analytical grade, and all the other chemicals were obtained from Merck and Co., Darmstadt, unless mentioned otherwise. Nitrocellulose filters for TCA (trichloroacetic acid) precipitation were purchased from Sartorius, Göttingen.

Nucleic acid extraction. About $5 \times 10^{8} \mathrm{PBS}$ (phosphate-buffered saline)-washed (3) cells from tissue culture or $1 \mathrm{~g}$ of tumor material after homogenization with sand in a mortar were suspended in $40 \mathrm{ml}$ of 0.01 M Tris (pH 7.4). Five milliliters of a $500 \mu \mathrm{g} / \mathrm{ml}$ solution of proteinase $\mathrm{K}$ (Merck, Darmstadt), $0.015 \mathrm{M} \mathrm{CaCl}_{2}$ and $5 \mathrm{ml}$ of a $10 \%$ solution of Sarkosyl (sodium laurylsarcosinate, Ciba-Geigy, Basle) were added while shaking on a Boskamp Mixomat and the solution was incubated for $30 \mathrm{~min}$ at $37^{\circ} \mathrm{C}$. The lysate was extracted twice with equal volumes of phenol (saturated with $0.01 \mathrm{~m}$ Tris, $0.001 \mathrm{~m}$ EDTA, pH 7.4). For highly diluted preparations, partially saturated phenol (nine parts phenol, one part buffer, as above, $\mathrm{pH} 7.4$ ) was used which reduced the volume of the aqueous phase by about $20 \%$ per step. Thereafter, the aqueous phase was either reextracted with phenol and then dialyzed against 0.02 M Tris ( $\mathrm{pH} 7.4$ ) or reextracted with chloroform containing $4 \%(\mathrm{v} / \mathrm{v})$ isoamyl alcohol. Subsequently, it was shaken three times with diethylether. The ether was removed by vigorous bubbling with nitrogen gas for at least $1 \mathrm{hr}$. For large-scale preparative work the nucleic acid mixture was sonicated for $3 \times 10 \mathrm{sec}$ at about $50 \mathrm{~W}$ with a Branson sonicator equipped with a microtip in order to avoid problems with high viscosity when harvesting the gradients.

Density gradient centrifugation. Centrifugations were performed with a $50 \mathrm{Ti}$ fixed-angle rotor in a Beckman L3-50B preparative ultracentrifuge. Up to $50 \mathrm{OD}_{260}{ }^{1 \mathrm{~cm}}$ units of nucleic acids were run in one tube $(13.5 \mathrm{ml})$. For preparation of the gradients, sodium citrate and sodium pyrosulfite were adjusted to 0.015 and $0.01 \mathrm{M}$, respectively. By adding $1.0 \mathrm{~g}$ of $\mathrm{KI}$ per $\mathrm{ml}$ of the above solution, a refractive index of about 1.4290 was obtained. The centrifuge tubes were filled to the top and centrifuged at $43,000-45,000 \mathrm{rpm}(\mathrm{av}, 25,500 \mathrm{~g})$ at $23^{\circ} \mathrm{C}$ for $72 \mathrm{hr}$. The rotor was stopped without braking, and the tubes were pierced from the bottom with a 16-gauge needle. The OD was monitored with a Hitachi $181 \mathrm{UV}-\mathrm{V}$ is spectrophotometer equipped with a continuous flow cell- 
cuvette with $1-\mathrm{cm}$ pathway having a volume of about $100 \mu$ l. About 25 fractions were collected from each gradient. Ten microliters of every third or fourth fraction were removed to measure the refractive index in a Zeiss refractometer. Fractions containing DNA or RNA were pooled, placed into dialysis bags (Visking, Serva, Heidelberg) and dialyzed at $4^{\circ} \mathrm{C}$ with gentle stirring against $0.1 \times \mathrm{SSC}(15 \mathrm{~mm}$ sodium chloride, $1.5 \mathrm{~mm}$ sodium citrate), $5 \mathrm{~mm}$ Na-pyrosulfite followed by extensive dialysis for about 4 days against several changes of $0.01 \mathrm{M}$ Tris $(\mathrm{pH}$ 7.4).

Determination of radioactivity. Due to strong quenching effects from traces of iodine, the radioactivity of tritium-labeled samples cannot be measured directly. Even after TCA precipitation some iodine occasionally remained bound to the filters and could not be removed by simple washing. Therefore, the filter disks were fixed to a solid support by needles and incubated for $2 \mathrm{hr}$ at $80^{\circ} \mathrm{C}$. This procedure allowed all iodine to sublime. Afterward, the filters were moistened with $100 \mu \mathrm{l}$ of water and placed into scintillation vials which were filled with $10 \mathrm{ml}$ of scintillation mixture $133 \%$ Triton X-100, Rohm and Haas, Frankfurt/Main; $66 \%$ toluene, $4 \mathrm{~g} /$ liter of PPO, $0.2 \mathrm{~g} /$ liter of POPOP, Zinsser, Frankfurt/Main). The samples were counted after shaking for $30 \mathrm{~min}$ at $4^{\circ} \mathrm{C}$. This method gives the most reproducible results for all materials collected on filters because it avoids selfadsorption and inconsistencies for geometric reasons (Ref. (4) and Bornkamm ${ }^{3}$ ).

Liquid hybridization. Measurements of reassociation kinetics were performed to test for the purity of RNA. The procedure has been described elsewhere (5).

\section{RESULTS AND DISCUSSION}

In order to determine whether or not any part of the nucleic acid adsorption spectrum could be detected in the presence of KI, the OD of KI solutions with and without nucleic acid was measured in the range of $220-320 \mathrm{~nm}$ against a reference cuvette containing a similar concentration of KI alone. Below $280 \mathrm{~nm}$ (region A in Fig. 1) the absorption of the KI solution was too high ( $>3$ OD units) to give a real differential spectrum. However, there was a rapid decline in the absolute OD above $280 \mathrm{~nm}$ yielding a peak at about $285 \mathrm{~nm}$ in the difference spectrum (Fig. 1 , dashed line) when the sample contained nucleic acid. Therefore, it should be possible at least to locate the positions of the nucleic acids in fractions from KI density gradients by measuring the OD at about 285 $\mathrm{nm}$. Quantitation by this procedure was rather difficult because of a slight dependence on KI concentration and, more importantly, inter-

"Personal communication. 


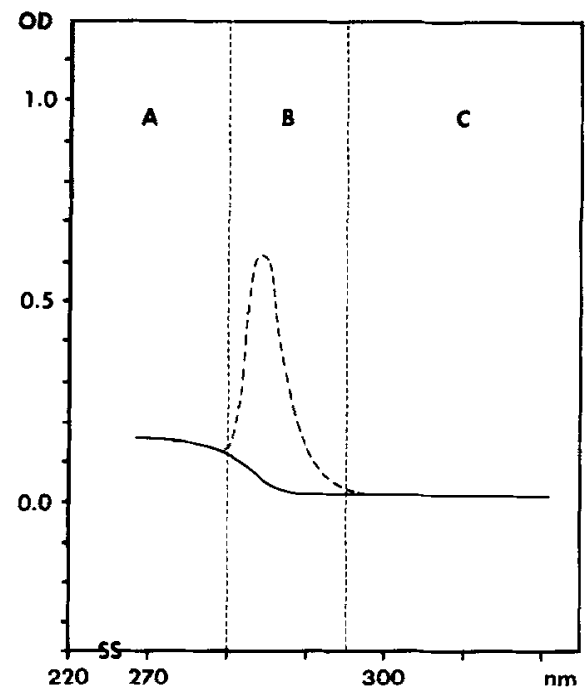

FIG. 1. Comparison of OD profiles of a KI solution containing RNA (full line in A and C, dashed line in B) and one without RNA (full line). The spectrum was measured in a Gilford 240 spectrophotometer with a reference solution of similar KI concentration.

ference by varying amounts of free iodine. In practice, measurements at $288 \mathrm{~nm}$ gave the best results and showed that DNA banded consistently at a density of $<1.530 \mathrm{~g} / \mathrm{ml}$ (refractive index, $n$, of $<1.4250$ ) and RNA banded at a density of $>1.570 \mathrm{~g} / \mathrm{ml}(n>1.4320)$.

To demonstrate that RNA and DNA can be separated by centrifugation in KI gradients, one species of nucleic acid was used in ODmeasurable amounts whereas the other was radioactively labeled and added in trace amounts only. The results are shown in Fig. 2 . Since
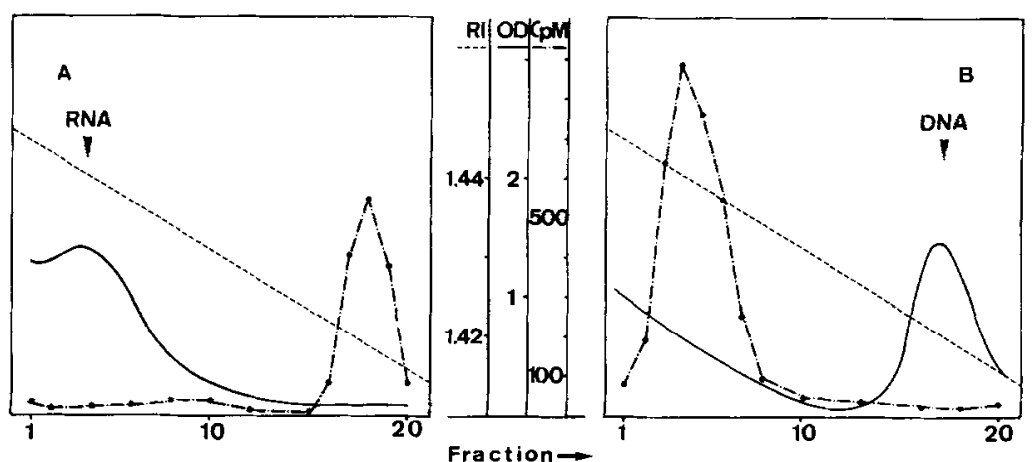

FIG. 2. OD profiles of KI gradients. Gradient A contained about $1.2 \mathrm{mg}$ of DNA and trace amounts $(14 \mu \mathrm{g})$ of $\left[{ }^{3} \mathrm{H}\right] \mathrm{RNA}$. Gradient B contained $1 \mathrm{mg}$ of RNA and $6 \mu \mathrm{g}$ of $\left[{ }^{3} \mathrm{H}\right]$ DNA. The OD was measured at $288 \mathrm{~nm}$. $\mathrm{n}$, refractive index. 


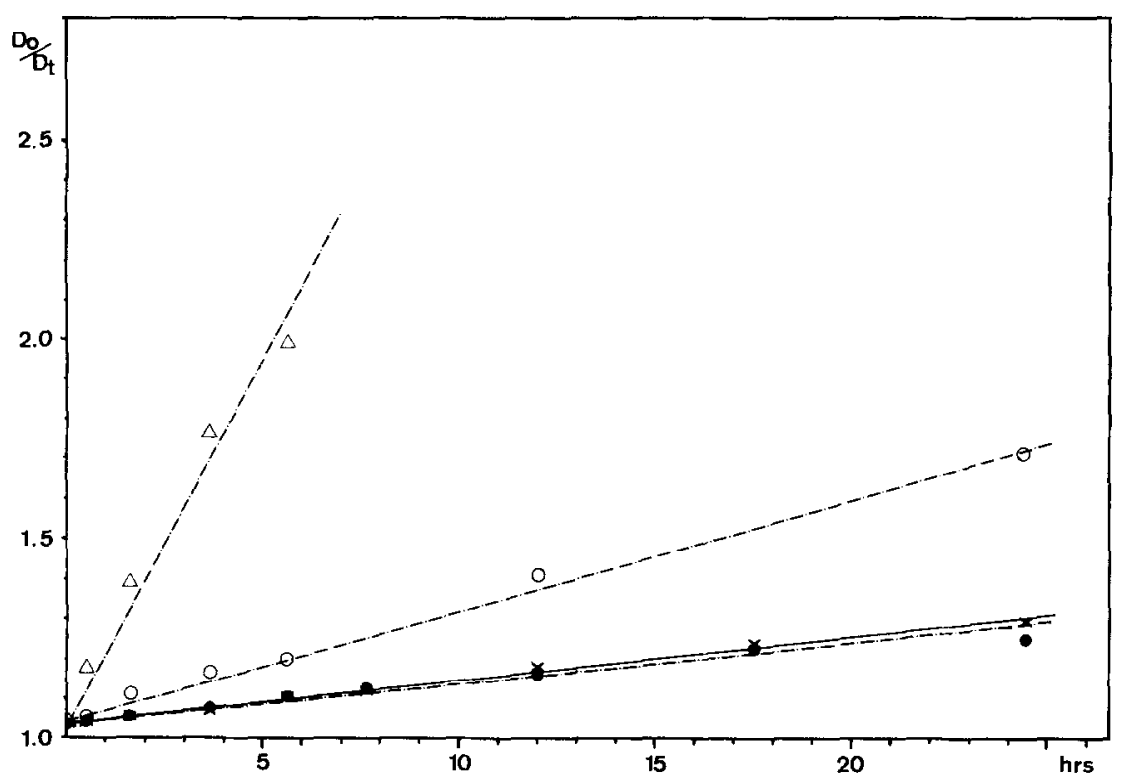

FIG. 3. Reassociation kinetics of $500 \mu \mathrm{g}$ of RNA separated by KI gradicnt centrifugation from $700 \mu \mathrm{g}$ of Epstein-Barr virus (EBV)-DNA containing cellular DNA (P3 HR-1). Reassociation was performed at $66^{\circ} \mathrm{C}$ in $1 \mathrm{M} \mathrm{NaCl}, 0.5 \mathrm{M}$ Tris ( $\mathrm{pH} \mathrm{7.0)} \mathrm{(5).} \mathrm{The}$ nucleic acids were fragmented and denatured in capillaries by indirect sonication with 100 $\mathrm{W}$ for $10 \mathrm{~min}$ (Branson sonicator, macrotip) followed by heating to $120^{\circ} \mathrm{C}$ for $10 \mathrm{~min}$. Double and single strands were quantitated by chromatography on hydroxylapatite (DNAgrade HTP, Bio-Rad. München). The full line $(x--x)$ gives the values for the RNA from the gradient, the dashed lines represent controls. The filled circles show the reassociation of calf thymus (CT) DNA, the open circles and triangles represent artificial mixtures of $1 \mathrm{mg}$ of CT-DNA with 12.5 and $140 \mathrm{ng}$ of EBV-DNA, respectively.

hybridization with RNA often requires extreme purity and lack of DNA contamination, the efficiency of separation was tested in a very sensitive test system. DNA of a Epstein-Barr virus (EBV)-producing cell line P3 HR-1 containing more than 800 EBV genomes $\left(1.3 \times 10^{-13} \mathrm{~g}\right)$ per average single cell $\left(6 \times 10^{-12} \mathrm{~g}\right.$ of DNA) was mixed with yeast RNA and subjected to gradient separation. Figure 3 shows that no viral DNA could be demonstrated in the RNA peak of the KI gradient. This method would have allowed detection of 0.25 or less viral genome equivalents $\left(0.4 \times 10^{-16} \mathrm{~g}\right)$ per cell $\left(6 \times 10^{-12} \mathrm{~g}\right)$ which excludes crosscontamination higher than $0.03 \%$. It is still possible that considerably larger amounts of nucleic acid per gradient would lead to traces of impurities. In this case, however, enzymatic digestion could be used to eliminate the contaminating species from either band without losing significant quantities of the total nucleic acids.

Several measurements have been performed to correlate the refractive index $(n)$ with the density of the solutions. The observed values were 

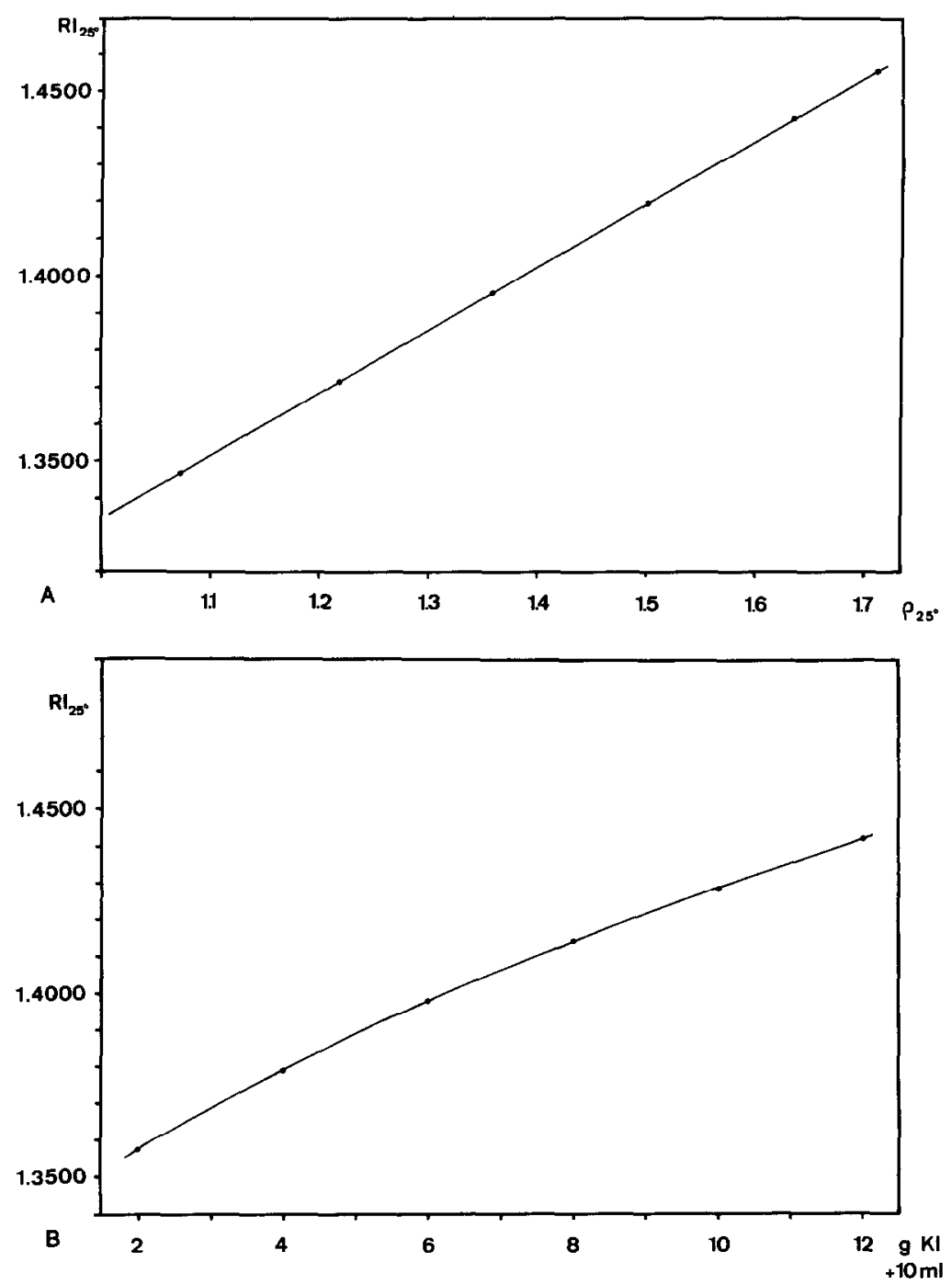

FIG. 4. (A), Linear correlation of density and refractive index $n$ at $25^{\circ} \mathrm{C}$. (B), nonlinear correlation of refractive index and weight of $\mathrm{KI}$ added to $10 \mathrm{ml}$ of buffer $(0.02 \mathrm{M}$ Tris, $0.015 \mathrm{M}$ Na-citrate, $0.01 \mathrm{M}$ Na-pyrosulfite, $\mathrm{pH} 7.05$ ).

subjucted to the least-squares method and the following equations were derived:

$$
\begin{aligned}
n^{25^{\circ}} & =0.17136 \rho^{25^{\circ}}+1.1628, \\
n^{25^{\circ}} & =0.0723 \mathrm{~g} / \mathrm{ml} \mathrm{KI}+1.3357, \\
\rho^{25^{\circ}} & =0.6996 \mathrm{~g} / \mathrm{ml} \mathrm{KI}+1.0087, \\
\rho^{25^{\circ}} & =5.8356 n^{25^{\circ}}-6.7858, \\
\mathrm{~g} / \mathrm{ml} \mathrm{KI} & =8.2964 n^{25^{\circ}}-11.0818, \\
\mathrm{~g} / \mathrm{ml} \mathrm{KI} & =1.4294 \rho^{25^{\circ}}-1.4419 .
\end{aligned}
$$


Figure 4A shows a graphical presentation of the correlation between $n$ and $\rho^{25^{\circ}}$. Figure $4 \mathrm{~B}$ gives a nomogram relating the weight of solid $\mathrm{KI}$ to be added to a given volume of buffer in order to obtain a particular value of $n$.

These results show that potassium iodide gradients present a reliable and efficient method for simultaneous purification of RNA and DNA from cell cultures or tumor materials. The equations generated here should also be of general benefit for workers using KI gradients for other purposes such as isolation of DNA fragments from agarose gels (6).

\section{ACKNOWLEDGMENTS}

I am indebted to Miss Monika Rak for excellent technical assistance, to Dr. H. zur Hausen for his interest and helpful discussions, and to Dr. Gary Hayward for reading the manuscript. The work was supported by the Deutsche Forschungsgemeinschaft (SFB $118)$.

\section{REFERENCES}

1. Anet, R., and Strayer, D. R. (1969) Biochem. Biophys. Res. Commun. 37, 52-58.

2. De Kloet, S. R., and Andrean, B. A. G. (1971) Biochim. Biophys. Acta 247, 519-527.

3. Dulbecco, R., and Vogt, P. (1954) J. Exp. Med. 99, 167.

4. McKenzie, R. M., and Gholson, R. K. (1973) Anal. Biochem. 54, 17-31.

5. Wolf, H., Werner, J., and zur Hausen, H. (1975) Cold Spring Harbor Symp. Quant. Biol., Vol. XXXIX Tumor Viruses. 791-796, Cold Spring Harbor Laboratory 1975.

6. Blin, N., von Gabain, A., and Bujard, H., (1975) FEBS Letters 53, 84-86. 